\title{
Hotspots within hotspots? Hammerhead shark movements around Wolf Island, Galapagos Marine Reserve
}

\author{
Alex Hearn · James Ketchum • A. Peter Klimley • \\ Eduardo Espinoza $\cdot$ Cesar Peñaherrera
}

Received: 7 July 2009/ Accepted: 19 April 2010/Published online: 9 May 2010

(C) The Author(s) 2010. This article is published with open access at Springerlink.com

\begin{abstract}
Are pelagic species such as sharks and tuna distributed homogenously or heterogeneously in the oceans? Large assemblages of these species have been observed at seamounts and offshore islands in the eastern tropical Pacific, which are considered hotspots of pelagic biodiversity. Is the species distribution uniform at these hotspots or do species aggregate at a finer spatial scale at these sites? We employed three techniques to demonstrate that the aggregations of scalloped hammerhead sharks, Sphyrna lewini, and other pelagic species were confined to the southeastern corner of Wolf Island in the Galapagos Marine Reserve. Coded ultrasonic transmitters were placed on individuals at this site and at another aggregation site at Darwin Island, separated from Wolf by $40 \mathrm{~km}$, and they were detected by monitors moored at the southeastern corner of Wolf Island and rarely by monitors deployed at other sites around the island. Hammerhead sharks, carrying depth-sensing continual transmitters, were tracked for twoday periods in a vessel and shown to reside a disproportionately large fraction of their time at the southeastern corner. Visual censuses were carried out seasonally at the eight monitor sites at Wolf Island, recording the abundance of one species of tuna, four species of jacks, and a number
\end{abstract}

Communicated by R. Lewison.

A. Hearn $(\bowtie) \cdot$ J. Ketchum · A. P. Klimley

University of California, Davis,

One Shields Ave, Davis, CA 95616, USA

e-mail: arhearn@ucdavis.edu

\author{
A. Hearn · C. Peñaherrera \\ Charles Darwin Foundation, Galapagos Islands, Ecuador \\ E. Espinoza \\ Galapagos National Park Service, Galapagos Islands, Ecuador
}

of other species. The highest diversity and abundance of these species occurred in the southeastern corner of the island. Our results support the use of hammerhead sharks as indicator and umbrella species for pelagic hotspots on a fine scale.

\section{Introduction}

Since the turn of the century, an increasing body of literature has pointed to the decline of shark populations worldwide (Baum et al. 2003; Baum and Myers 2004; Crowder and Myers 2001), which may lead to cascade effects throughout the marine trophic web, due to changes in both predation rates and predation avoidance behavior (Heithaus et al. 2008; Myers et al. 2007; Stevens et al. 2000). This concern, coupled with alarming signs of overfishing of commercial fish stocks (Pauly et al. 1998; Pauly and Watson 2003; Worm et al. 2006; Ovetz 2007), has contributed to the discussion of the need to create oceanic marine reserves to protect the pelagic assemblage (Roberts 2003; Alpine and Hobday 2007), and in particular, apex predators. In the eastern tropical Pacific (ETP), progress has been made in this sense, with the creation of marine reserves around oceanic islands and archipelagos, notably, the Galapagos, Cocos, and Malpelo Islands, around which commercial fisheries are excluded. The Galapagos Islands also possess a coastal zonation scheme, which includes no-take zones, dive areas, and local fishing grounds, the latter of which make up $83 \%$ of the total coastline (Heylings et al. 2002).

Oceanic islands, like seamounts, provide structure to both ocean bathymetry and current patterns and are associated with hotspots of pelagic biodiversity (Worm et al. 2003) and in particular with apex predators (Stevenson 
et al. 2007). There are several non-exclusive theories as to why these features are sites of relatively high pelagic biodiversity (see Genin 2004 for review). It is thought that downstream generation of eddies might trap either advected plankton or enhanced phytoplankton resulting from localized upwelling (Barton 2001; Boelhert and Genin 1987) or that the features might provide shelter or resting areas from which to forage (Lorance et al. 2002; McFarland and Levin 2002). The divergence of currents due to upstream blocking creates a zone of weak currents, which can also lead to entrapment and accumulation of plankton (Hamner and Hauri 1981). Hamner et al. (1988, 2007) suggest that planktivorous fishes on the upstream reef face form a "wall of mouths" that remove most of the zooplankton from the water near the reef face before that water physically impinges upon the reef surface. A further explanation for the aggregations of some species at hotspots, from which they make diel migrations away at night, is that the island or seamount may serve as a landmark. Providing a perceptible physical property, such as the local magnetic field intensity, these landmarks are analogous street signs along a highway, and they could be used for guidance during daily and seasonal migrations. Species making diel feeding migrations away from seamounts or fish aggregating devices include skipjack tuna (Yuen 1970), yellowfin tuna (Holland et al. 1990), and hammerhead sharks (Klimley 1993), among others.

The scalloped hammerhead shark (Sphyrna lewini) is found in large aggregations around several islets and seamounts in the ETP (Arauz and Antoniou 2006; Bessudo et al. (unpublished data); Hearn et al. 2008; Klimley and Nelson 1984). Prior studies suggest that hammerheads display a diel pattern in relation to their use of seamounts (Klimley and Nelson 1984), forming schools around seamounts during the day and dispersing to forage in open water at night. This diel pattern has also been observed in Malpelo (Bessudo et al. unpublished data) and Galapagos (Ketchum et al. 2009). However, their fine-scale spatial dynamics around a particular structure has been described only once (Klimley et al. 1988). Hammerheads at Espiritu Santo seamount in the Gulf of California did not appear to change their position relative to the seamount in response to changing tidal patterns (Klimley and Nelson 1984). Bessudo et al. (unpublished data) suggest that the distribution of tagged sharks around Malpelo varies throughout the year on a longer timescale, coinciding with changes in currents. In any case, little is known about the spatial dynamics of hammerheads and other pelagic species around these oceanic features. Without this understanding, it is difficult to assess their value as conservation tools for the pelagic community.

Ultrasonic tags have been used to track the movements of salmon (Welch et al. 2008) and sturgeon (Kelly et al. 2007; Heublein et al. 2009) in rivers and coastal-estuarine environments, to track the short-scale movements of several sharks (Holland et al. 1992; Klimley 1993; Klimley et al. 2002; Klimley and Nelson 1984) and rays (Klimley et al. 2005), and to study site fidelity of sharks at seamounts (Klimley and Nelson 1984) and tuna at fish aggregating devices (FADs) (Klimley and Holloway 1999). In 2006, a regional network of scientists in the ETP deployed arrays of hydrophones at sites around Cocos, Galapagos, and Malpelo Islands (see www.migramar.org) and began an ambitious study to understand local and regional movement patterns of several shark species, including scalloped hammerhead sharks.

Using a combination of ultrasonic tagging and listening arrays, onboard tracking and diver surveys, this study addresses the spatial behavior of scalloped hammerhead sharks around Wolf Island, in the Galapagos Marine Reserve, and how this may be applicable to the entire pelagic assemblage. To what extent do sharks utilize the entire available habitat around oceanic islets and seamounts? Do they display site fidelity? Do sharks from other islands display the same site fidelity upon migrating to Wolf? Might hammerheads be suitable indicator species to represent the spatial composition of pelagic assemblage?

\section{Materials and methods}

Study site

The Galapagos Islands lie in the eastern tropical Pacific, straddling the equator at $1,000 \mathrm{~km}$ from the coast of continental Ecuador. The islands are volcanic in origin and are characterized by steep cliffs and seabed, dropping off to several hundred meters depth close to the coastline. The archipelago is made up of 13 major islands and over 100 islets and emergent rocks (Snell et al. 1996), along with an unknown number of shallow and deep seamounts.

The Galapagos Marine Reserve (GMR) covers an area of approximately $138,000 \mathrm{~km}^{2}$ from a baseline connecting the farthest points of the major islands to a distance of $74 \mathrm{~km}$ (Fig. 1). Conditions within the GMR are affected by several major ocean current systems: the warm Panama current from the north and the cool Humboldt Current from the south join with the westward flowing South Equatorial Current (Houvenaghel 1984). Their relative strength gives rise to two distinct seasons-a warm rainy season from December to May, and a cool, dry season characterized by an almost constant light drizzle, known as garua, from June to November. To the west, the Cromwell Current flows at depth along the equator and rises as it impinges on the Galapagos platform, creating upwelling conditions associated with high productivity. The interactions of these currents give rise to several biogeographic marine areas 
within the GMR - a cool western area, a warm northern zone, and a central mixed zone, each with a characteristic suite of marine communities (Edgar et al. 2004).

Darwin and Wolf Islands are located in the remote far north of the archipelago, at a distance of $38 \mathrm{~km}$ from one another, within the warm zone. Water temperature generally fluctuates between 22.5 and $27^{\circ} \mathrm{C}$ throughout the year, peaking in February (Banks 2002). They are two of the smallest islands of the archipelago-Darwin has a surface area of 106.3 hectares and Wolf is approximately 134.4 hectares (Black 1973) —and their rocky coastline drops rapidly into waters of depths greater than several hundred meters. Both islands are surrounded by a small number of islets and exposed rocks.

Commercial fishing is prohibited throughout the GMR. A coastal zonation scheme, which came into effect in 2002, but was not implemented until 2006 (Calvopiña et al. 2006), permits limited human activities such as tourism and small-scale fishing (for lobster, sea cucumber, rockfish, and some small pelagics) by local fishers at different sites. It also provides for a few small no-take zones, including the Arch at Darwin Island (but none of the main island), and a stretch including a tourism zone on the southeastern coast of Wolf, which together make up $17 \%$ of its total coastline, although the seaward limit of its extension is ambiguous (Heylings et al. 2002). Although all shark species are protected within the GMR, there is evidence that an unquantified amount of shark fishing occurs to supply the growing demand for shark fins, both by local fishers and by industrial long-liners that enter the GMR illegally (Reyes and Murillo 2007).

\section{Surveys}

Scientists and dive guides were trained to identify and count sharks and other pelagic organisms. Visual censuses were carried out at six locations surrounding the island. Pairs of divers were asked to hang in mid-water (approximately $15-20 \mathrm{~m}$ depth) with their backs to the rocky reef and to record (to species level where possible) all pelagic organisms (including any fish not strictly associated with the reef) seen on a 30-minute drift dive or on a slow swim in one direction when there was no current. Counts were recorded on slates and verified on the surface with the help of field-identification guides (Grove and Lavenberg 1997; Human and Deloach 2003). Surveys were carried out in

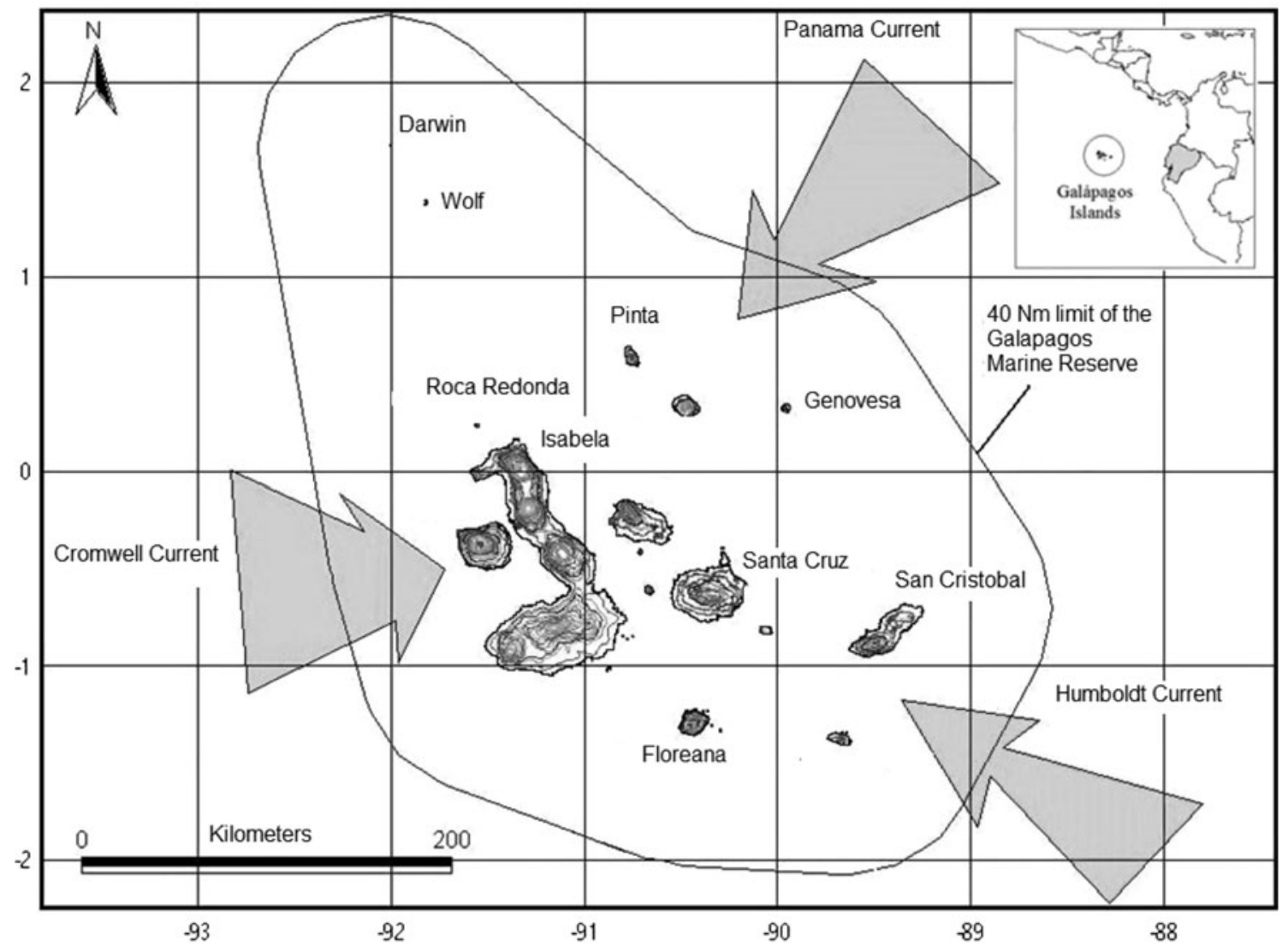

Fig. 1 The Galapagos Marine Reserve (GMR), showing major islands and oceanic currents affecting its marine biological community structure. Darwin and Wolf Islands are affected mainly by the warm Panama Current 
January, May, July, and November 2008, during daytime hours at least one hour after dawn and one hour before sunset. Divers were asked to estimate the visibility of the water column and to rate the current strength from 0 (no current) to 3 (strong current made census work difficult) (Table 1). Where appropriate, divers also noted the depth of the thermocline. However, although this varied, censuses always took place above the thermocline. Relative abundance of species or groups of species was calculated as the number of individuals recorded per diver hour, and expressed as the normalized averages for that site, to allow for intra-species comparison. For example, the highest relative abundance of yellow snappers was observed at Shark Point (a total of 76 individuals over 13.78 diver hours $=5.5$ ind.diver. $\mathrm{h}^{-1}$ ). The relative abundance of yellow snappers at all sites was therefore divided by this value, thus normalizing the data from 0 to 1 . This was repeated for each species.

Ultrasonic tag detection and tracking

Hammerhead sharks were fitted with ultrasonic tags (Vemco, Ltd., V16, $95 \mathrm{~mm}$ long, $36 \mathrm{~g}$ in air, $16 \mathrm{~g}$ in water, 157-160 dB, >3 years battery life), which emit a coded signal at $69 \mathrm{kHz}$ with a random delay of 40-140 s, to avoid successive signal collisions between two tags. The tags were fitted externally by free diving among the sharks and inserting the tags into the musculature of the sharks behind the dorsal fin with the use of a pole spear. During two cruises in July and October 2007, 61 hammerhead sharks were tagged between Rockfall and Shark Point, in Wolf Island, to determine site fidelity behavior. In October 2007, 10 hammerhead sharks were tagged at Darwin Arch to determine whether sharks from other islands also choose to visit sites at Wolf (Table 2). Tag-detecting ultrasonic receivers (Vemco Ltd., VR-02 and VR-02 W) were deployed at the six locations around Wolf, and at Darwin Arch and on the western coast of Darwin, at a site called "The Stack" (Table 3). Receiver moorings consisted of a concrete base $(25 \mathrm{~kg})$ to which was attached a $3-\mathrm{m}$ rope with a buoy. Receivers were affixed to the rope at $2 \mathrm{~m}$ above the concrete base using heavy-duty cable ties. Due to vandalism, some rope moorings were replaced by steel cables once the study had been initialized.

Range tests for the ultrasonic receivers (the published detection range is $500 \mathrm{~m}$-see www.vemco.com) were performed at several of the study sites (East Bay, Shark Point and Anchorage in Wolf, and the Arch and Stack at Darwin). Three V16 tags were activated from a small dinghy and lowered by rope to a depth of $3 \mathrm{~m}$, adjacent to the receiver mooring at each study site. Using an onboard omni-directional hydrophone, we recorded the number of pulses from each tag over a 10-min period, or until each tag had pulsed at least three times. We then raised the tags and

Table 1 Sphyrna lewini. Summary of visibility $(\mathrm{m})$ and current conditions $(0=$ no current, $1=$ weak current, $2=$ strong current, and 3 = current too strong for census work) perceived by $\mathrm{N}$ divers during underwater census activities at sites around Wolf Island

\begin{tabular}{|c|c|c|c|c|c|c|c|}
\hline Month & Data & Shark Point & Rockfall & East Bay & Anchorage & Elephant & Pinnacle \\
\hline \multirow[t]{3}{*}{ Jan } & $\mathrm{N}$ & 18 & 7 & 2 & 2 & 3 & 8 \\
\hline & Vis & 18 & 14 & & 7 & 15 & 18 \\
\hline & Current & 0.75 & 2.25 & 0 & 0 & 0.6 & 1.75 \\
\hline \multirow[t]{3}{*}{ May } & $\mathrm{N}$ & 2 & & 2 & 2 & 2 & \\
\hline & Vis & 20 & & 20 & 15 & & \\
\hline & Current & 1 & & 1 & 1 & 0 & \\
\hline \multirow[t]{3}{*}{ Jul } & $\mathrm{N}$ & 2 & 2 & 2 & 2 & 3 & 2 \\
\hline & Vis & & 20 & 20 & & & \\
\hline & Current & 1 & 2 & 1 & 1 & 1.7 & 1 \\
\hline \multirow[t]{3}{*}{ Nov } & $\mathrm{N}$ & 2 & 2 & 2 & 2 & 2 & 2 \\
\hline & Vis & 15 & 10 & 20 & 10 & 12 & 20 \\
\hline & Current & 1 & 0 & & 1 & 1 & \\
\hline
\end{tabular}

Table 2 Sphyrna lewini. Summary of hammerhead sharks tagged by free divers in the Galapagos Marine Reserve in 2007

\begin{tabular}{llllll}
\hline Island & Month & Total length range $(\mathrm{m})$ & Females $(N)$ & Males $(N)$ & Unknown $(N)$ \\
\hline \multirow{2}{*}{ Wolf } & July 2007 & $1.2-2.3$ & 31 & 5 & 3 \\
& October 2007 & $1.4-2.2$ & 17 & 1 & 4 \\
\multirow{2}{*}{ Darwin } & October 2007 & $1.5-2.0$ & 9 & 0 & 1 \\
\hline
\end{tabular}


Table 3 Sphyrna lewini. Deployment information for ultrasonic receivers around Wolf and Darwin in 2007-2008

\begin{tabular}{lll}
\hline Site & Deployment date & Date last upload \\
\hline Elephant & $7 / 26 / 2007$ & $7 / 23 / 2008$ \\
Rockfall & $7 / 23 / 2006$ & $7 / 23 / 2008$ \\
Shark Point & $7 / 23 / 2006$ & $7 / 23 / 2008$ \\
East Bay & $7 / 24 / 2007$ & $7 / 23 / 2008$ \\
Pinnacle $^{\mathrm{a}}$ & $7 / 24 / 2007$ & $10 / 31 / 2007$ \\
Anchorage $^{\mathrm{b}}$ & $7 / 27 / 2007$ & $7 / 22 / 2007$ \\
Darwin Arch $_{\text {Darwin Stack }}^{7 / 25 / 2006}$ & $1 / 27 / 2008$ \\
\hline
\end{tabular}

${ }^{a}$ Monitor recovered damaged

b Monitors not replaced until 7/22/08

moved to a distance of $25 \mathrm{~m}$ from the receiver mooring and repeated the procedure. This was repeated at set intervals to a distance of $400 \mathrm{~m}$. We obtained the detection data from each receiver and compared this to the signals successfully detected by the hydrophone. With the exception of Darwin Arch, all sites detected $100 \%$ or greater (this occurred where tag collision prevented the hydrophone from deciphering a tag identity; however, the VR2 was able to decipher the signals reaching it on several occasions) to a distance of $150 \mathrm{~m}$, after which detection rates declined steadily at all sites (Fig. 2). The most rapid drop in detection rates corresponded to Shark Point and Darwin Arch, which are exposed sites and were also the sites with the greatest abundance of hammerhead sharks and the highest number of detections. We therefore did not apply a correction factor to each study site based on the detection range.

To obtain fine-scale information on the spatial dynamics of sharks around Wolf Island, we fitted two hammerhead sharks (in November 2007 and 2008, respectively) with continuous ultrasonic transmitters with incorporated temperature and depth sensors (Vemco Ltd., V22, depth range to $680 \mathrm{~m}$, temperature range $-5-35^{\circ} \mathrm{C}, 120 \mathrm{~mm}$ long, $40 \mathrm{~g}$ in water, $168 \mathrm{~dB}, 10$ days battery life). Each tag emitted pulses with coded temperature and depth data at $50 \mathrm{kHz}$ every second. The coded pulses were detected by a directional hydrophone attached to a Vemco-V110 Ultrasonic Receiver with an integrated GPS onboard a small motorized vessel, enabling us to track the shark. Sharks were tracked continuously for 44 and $48 \mathrm{~h}$.

\section{Analysis}

The detection zone of the underwater receivers did not cover the entire area of the site. A shark residing at a particular site might swim in and out of range of the

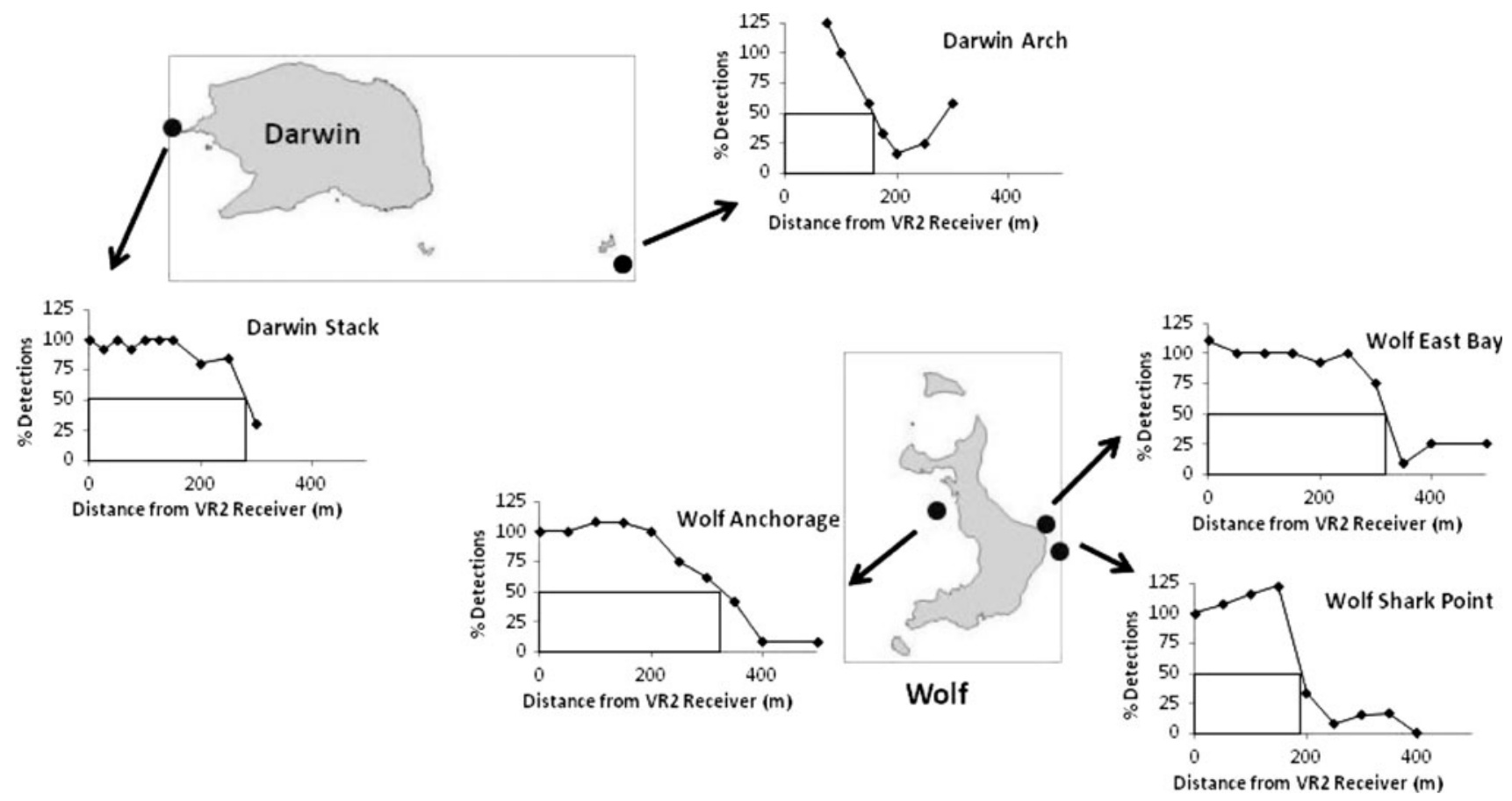

Fig. 2 Range test results: percentage detections of three V16 ultrasonic tags placed at $25-\mathrm{m}$ intervals for $10 \mathrm{~min}$ or at least three pulses for each tag, at different study sites around Darwin and Wolf Islands. Lines show distance for $50 \%$ detection rate. Note that detection rates greater than $100 \%$ occurred when VR2 W receivers detected pulses that collided and were not detected by the onboard hydrophone 
receiver while remaining at the site. If it did so while the tag was pulsing, the receiver would not detect that particular pulse. There is also the potential for collision of pulses when more than one tag emitted simultaneously, or where reflections from one tag off the seabed might interfere with the signal received by the tag-detecting automated receiver. A cutoff time must be determined as the interval between successive detections of the same tag that corresponds to a new visit.

VEMCO estimates the total time required for all tags to be detected at a site for different delay times, given that tag collision is more likely the greater the number of tags and the shorter the delay time (http://www.vemco.com/education/ Collision/collision_calc.php). The average update time for a tag when 20-25 tags are present around a receiver is $8-13.8 \mathrm{~min}$. We considered this together with the behavior of the sharks in order to determine a residence time cutoff period.

In a concurrent study (Ketchum and Hearn, unpublished data), we found that five continuously tracked hammerhead sharks (of estimated total lengths between 1.7 and $2.2 \mathrm{~m}$ ) generally spent the daytime hours swimming around Shark Point in ellipses up and down the coastline. The average speed of the sharks while behaving in this fashion was $0.44 \mathrm{~ms}^{-1}$. From the range tests above, we assumed a maximum detection diameter of 300 meters if a shark swam through the longest straight-line distance that would afford complete detection coverage by any given receiver. We conservatively took the time taken to complete this distance $(11 \mathrm{~min})$ as our cutoff interval, as any detection interval smaller than this indicates that the shark is still in the vicinity of the receiver. Although this interval might cause a bias toward short visits, the aim of this analysis was to provide a comparative insight between sites, rather than an absolute measure of residence.

Data were downloaded from ultrasonic receivers in July and November 2008. Sharks detected until November 15, 2008 , were assumed to be still in the system. The numbers of individuals observed and daily presence recorded per month around Wolf were tested for normality. Kruskal-Wallis oneway analyses of variance on ranks were used to determine whether significant differences existed between sites for monthly tag detections and hammerhead abundance estimates from surveys. Tukey post hoc tests were carried out to isolate the group or groups that differed from the others.

Rao's spacing test (Batschelet 1981) was used to determine whether the distribution of sharks at a particular site was uniform over time (for both times of day or months of the year). The critical value $(U)$ is calculated from the lengths of the arcs between each point $(T)$ and compared with the random distribution (where each arc would be of length $360^{\circ} / n$ ):
$U=1 / 2 \sum_{i=1}^{n} \mid T_{i}-\left(360^{\circ} / n\right)$

We used the Animal Movement 2.0 extension for ArcView 3.0 to determine the home range of the hammerheads tracked continuously over $48 \mathrm{~h}$. We used the first detection point for each 5-min interval (to correct for boat drift and maneuvers) to create fixed kernels using a smoothing factor calculated via least-squares crossvalidation (LSCV) (Worton 1989; Seaman and Powell 1996).

\section{Results}

Site specificity

The abundance of hammerhead sharks at Wolf varied spatially and temporally (Fig. 3), according to diver surveys. Significantly more hammerheads were observed in January than in the other months (Kruskal-Wallis, $P<0.05$ ), whereas the lowest abundances were recorded in the month of May. Overall, the greatest numbers of sharks were observed at Shark Point, where observed abundance was significantly greater than at Anchorage and Elephant on the south and west parts of the island (Kruskal-Wallis Test, $P<0.001)$. Hammerheads were also more abundant at Rockfall to the south and East Bay to the north of Shark Point than at sites on the west coast of the island. Pinnacle, at the northern point of Wolf, was the site of highest abundance in July, but no sharks were observed in November. Neither Rockfall nor Pinnacle was surveyed in May.

All but one of the tagged sharks were detected at Shark Point, whereas 46 and 48 sharks were detected at Rockfall and East Bay, at either side of Shark Point (Fig. 4). At each site, sharks were detected for a median of 8-11 days. In contrast, only half of the sharks were detected at Elephant and Anchorage, and for a median 1 and 0 days, respectively. The receiver station at Pinnacle was lost after the October 2007 download, so results for this site only reflect a 3-month period and are limited to those sharks tagged in July. A significant number of sharks tagged at Wolf were also detected at the Arch at Darwin Island (43 individuals, for a median of 4 days), and a small number (14 individuals for a median of 0 days) were also detected on the western side of Darwin. Shark Point had a significantly higher detection rate than the other sites $(P<0.05)$, whereas East Bay, Rockfall, and Darwin Arch all displayed higher detection rates than the remaining sites $(P<0.01)$, but not between each other. 
Fig. 3 Sphyrna lewini. Mean ( $\pm 95 \%$ CI) hammerhead relative abundance (numbers observed per diver hour) during visual censuses in January,

May, July, and November 2008 at different sites around Wolf Island, Galapagos. Coastline in bold indicates no-take zones (1.64 km; $17 \%$ of total coastline)

Fig. 4 Sphyrna lewini. Median (and quartiles) number of days present per site for 61 scalloped hammerheads tagged at Wolf Island in July and November 2007. Asterisks denote significant differences
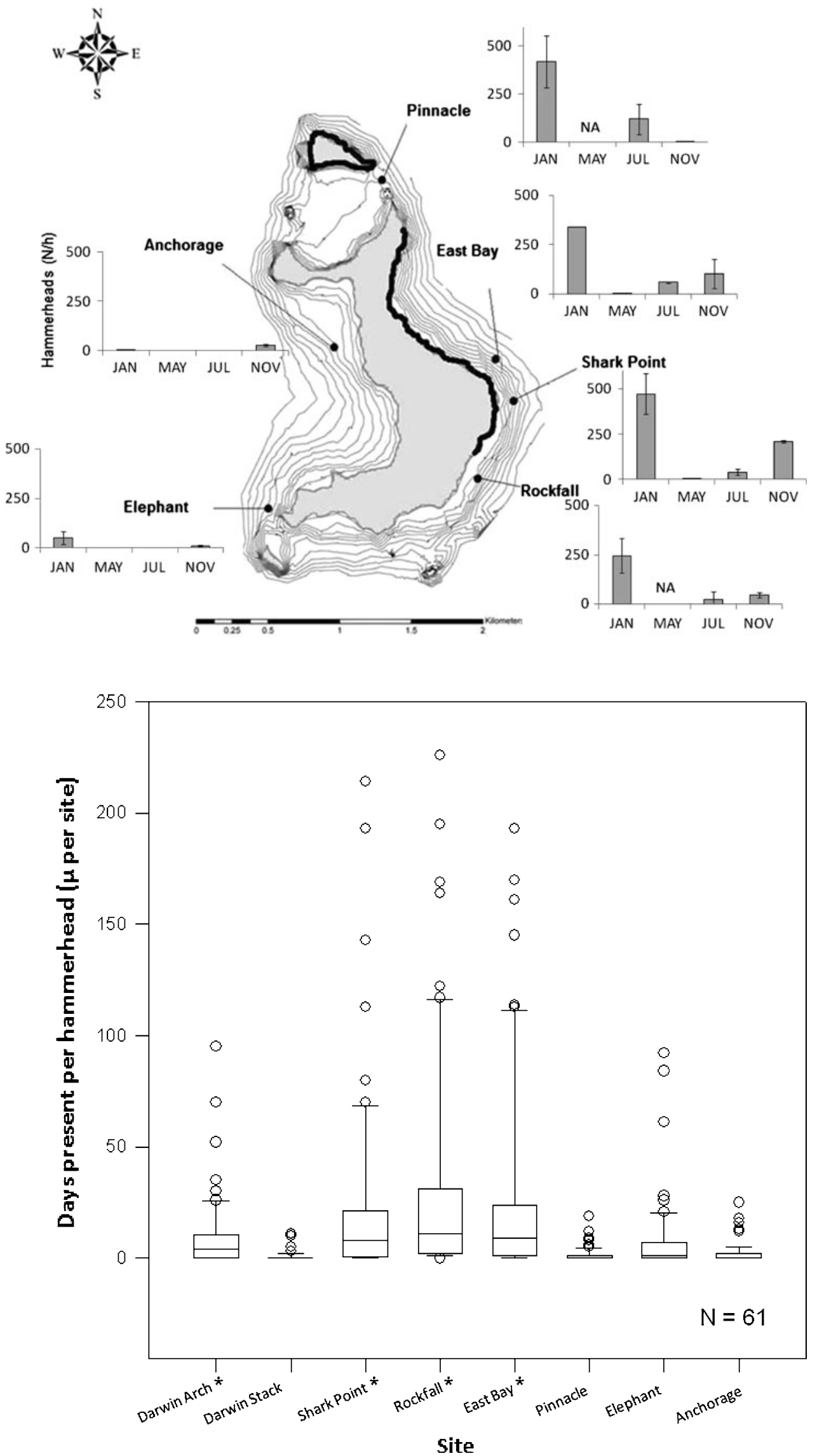
Tenure of residence

The majority of tagged hammerheads were detected at Wolf Island frequently over the weeks and months subsequent to tagging-15 individuals of the 22 tagged in October 2007 were still detected at Wolf past January 1, 2008. Only two individuals were detected for more than 2 days throughout the entire months of April and May, whereas numbers increased once more to eight in the JuneAugust period. By the end of October 2008, a period of 15 months after the tags were deployed, only five of the 39

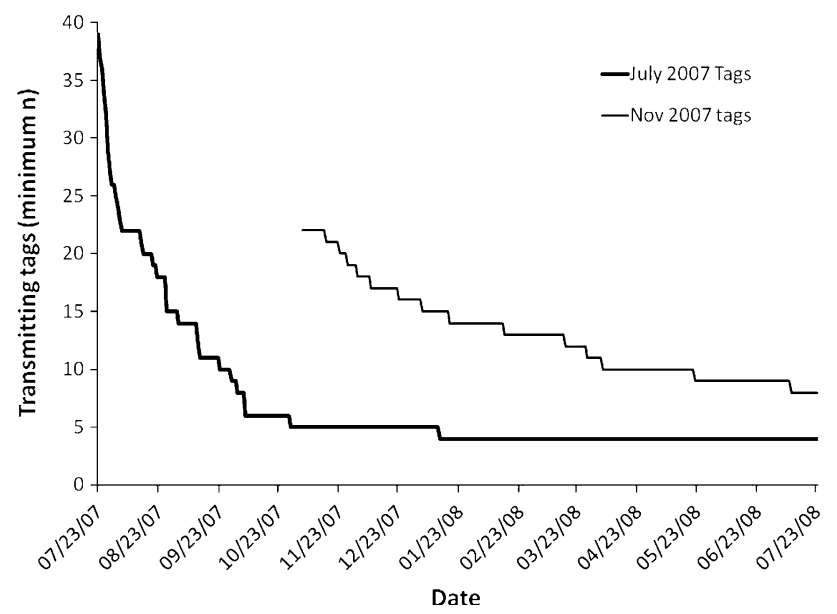

Fig. 5 Sphyrna lewini. Minimum number of tags still transmitting by date for each batch of hammerheads tagged at Wolf Island in 2007 individuals tagged in July 2007 were recorded by the receivers. A total of 13 tagged hammerheads were still being detected at the end of the study (Fig. 5). However, this must be considered a minimum rather than an absolute number of individuals still present, due to the possibility of tag loss-although this was not quantified, the difficulty of the tagging operation (free diving into close range with moving sharks) suggests that tag shedding may account for a significant proportion of the loss of tag signals as the study period proceeded. The monthly detections of a representative shark (HH \#6), a relatively small female (approximately $1.5 \mathrm{~m}$ total length), around Wolf Island is shown over the 12-month period (Fig. 6). This shark also migrated to Darwin Island over a distance of $70 \mathrm{~km}$ and back on two occasions, in September and March. The shark was absent from the entire array of listening stations for a 2-month period from March 24 to May 24. The migrations to Darwin and the absence in April and May appear to be representative of other individuals - \#14 was absent from February 5 to April 19 and then again from April 21 to July 11, \#38 was absent from March 17 to June 30, and \#24 was absent from April 12 to June. This shark spent most of its time at Wolf between the three sites at the southwestern corner, appearing to prefer the Rockfall in August, September, and October, then Shark Point from November to February. The number of individuals sharks detected at Wolf per day dropped from eight (at the end of February) to zero on several occasions between March and May 2008, before climbing once more in June (Fig. 7).
Fig. 6 Sphyrna lewini. Monthly detections of female scalloped hammerhead \#6 at sites around Wolf Island from July 2007 to July 2008. Each circle represents a period of one year divided into 12 months, starting with January. The length of the bars represents the number of detections at each site during that month for that individual

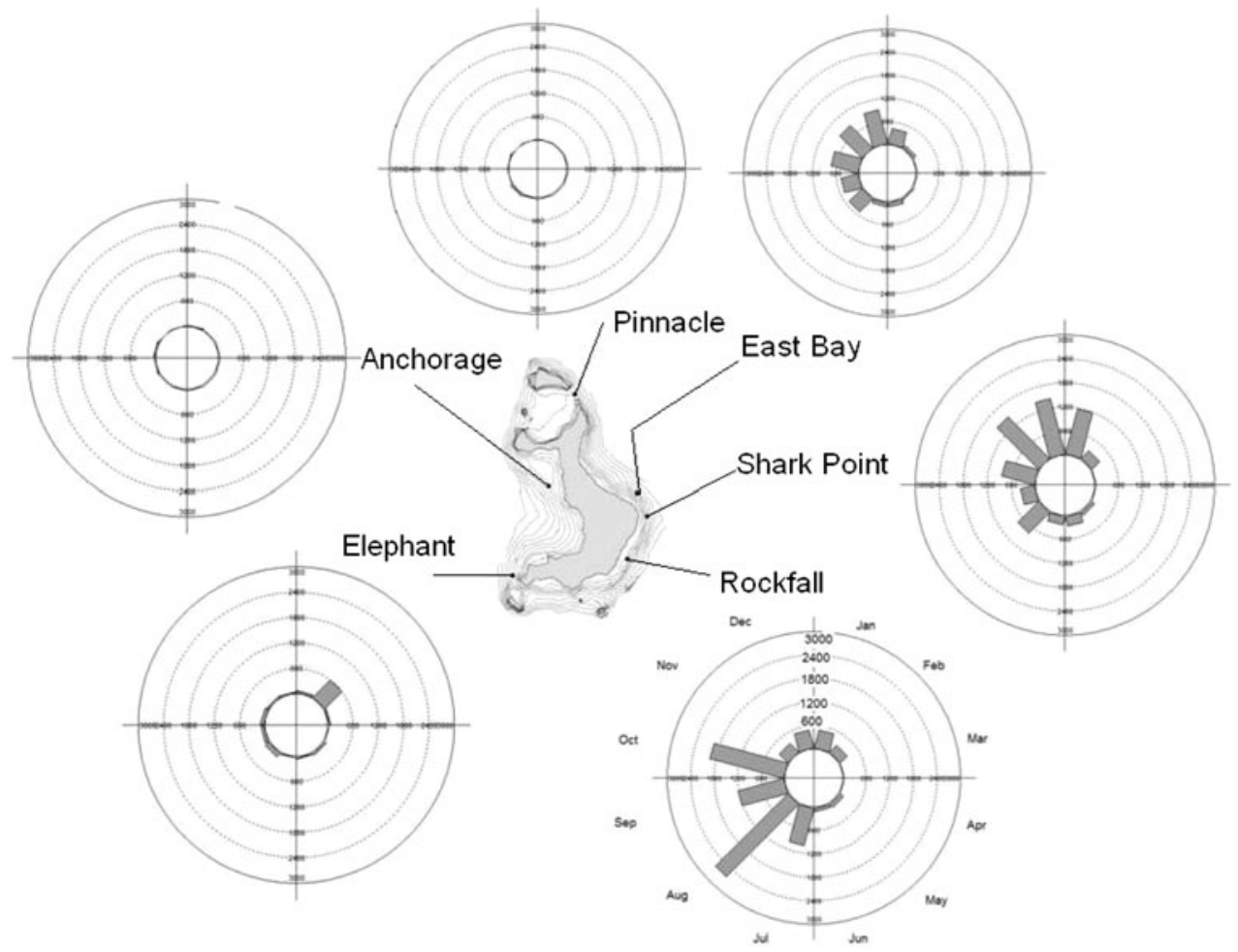




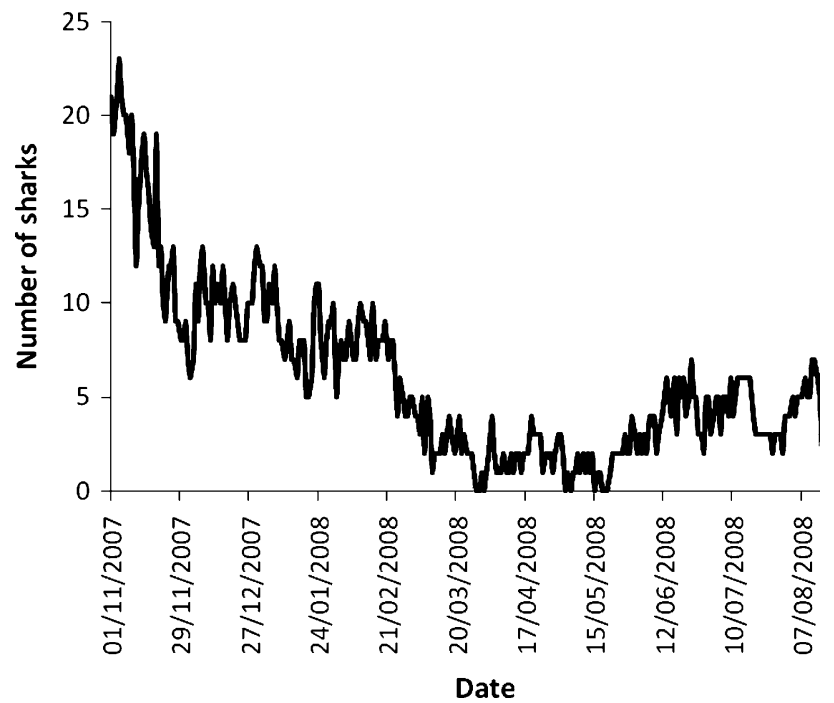

Fig. 7 Sphyrna lewini. Number of sharks tagged at Wolf Island detected around the island per day from November 2007 to August $2008(N=61)$
The sharks showed a significant preference for daylight hours at all sites around the island and during both warm (December through May) and cool seasons (June through November). Shark \#10 for example, a 2-m female, was generally first detected at Shark Point around dawn at $0600 \mathrm{~h}$ and generally left at dusk at $1800 \mathrm{~h}$ in both August (Rao's Spacing Test, $P<0.001$ ) and December (Rao's Spacing Test:, $P<0.001$ ) (Fig. 8). A small number of nighttime detections in August in comparison with a nearcomplete absence in December show that the shark did make some sporadic nocturnal appearances to the site in the former month.

A male and female hammerhead tracked for 44 and $48 \mathrm{~h}$, respectively, showed a high level of fidelity to the southeastern corner of Wolf-in both cases, the $50 \%$ kernel of the spatial distribution of its movements over 2 days is almost identical, around Shark Point, limited to the north by East Bay and to the south by Rockfall (Figs. 9, 10). The male tracked in November 2007 restricted its movements
Fig. 8 Sphyrna lewini. Scatterplot (below) of detections of hammerhead shark \#10 at Shark Point, Wolf Island. Horizontal gray shading from 00:00 to 06:00 and from 18:00 to 00:00 denotes approximate nighttime period. Vertical shading displays data points used for circular analysis (above) of diel behavior for August 2007 (cool season) and December 2007 (warm season). For each circular graph, bars represent the number of detections in that hour during the month. The direction of the arrow shows the mean time, the length is the concentration

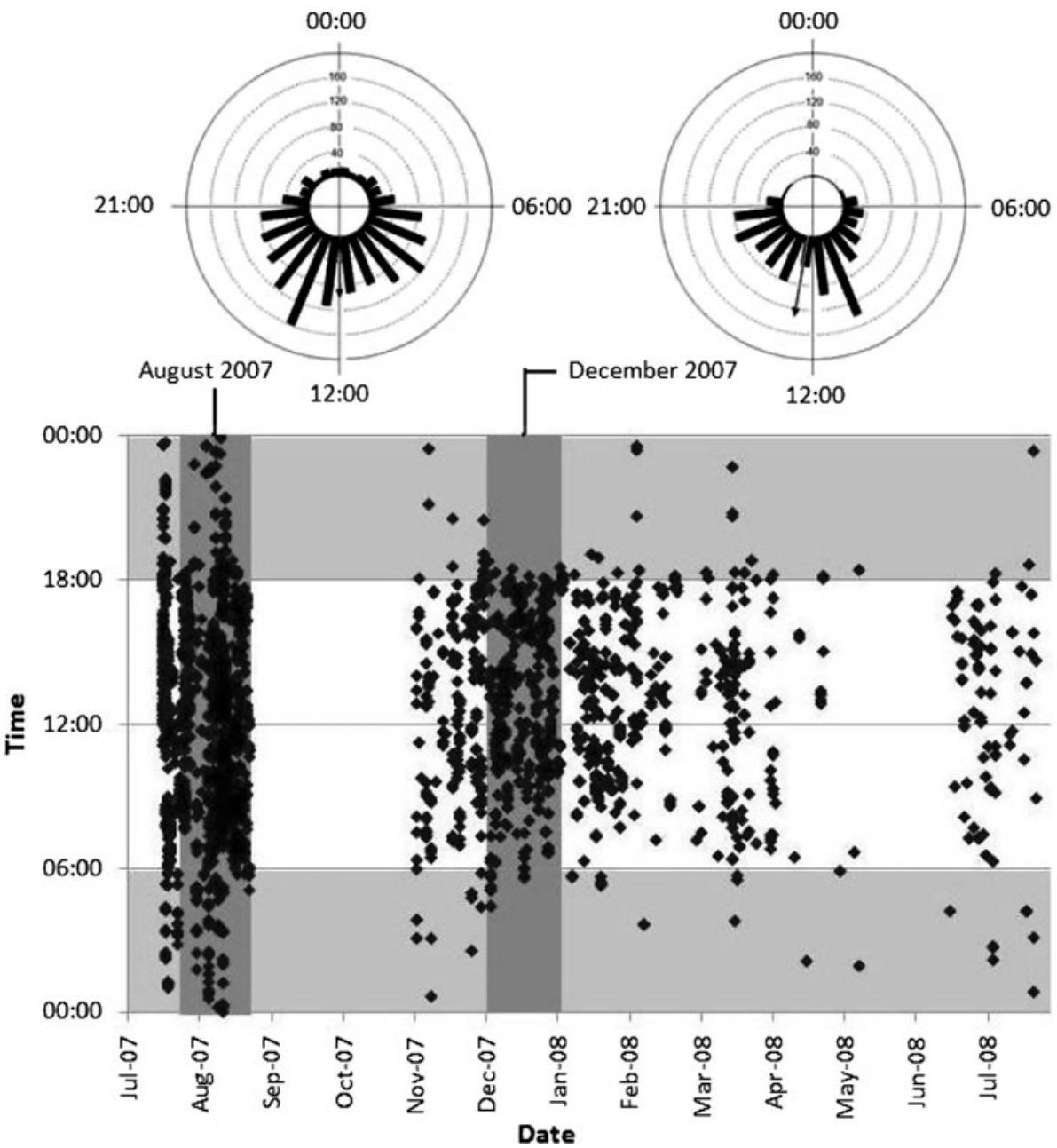


to coastal waters around this area, only leaving the immediate vicinity of Wolf on one evening for a short distance of $0.93 \mathrm{~km}$ to the southeast (Fig. 9). The shark maintained a swimming depth shallower than $50 \mathrm{~m}$ throughout the entire track, but displayed a preference for the 24-36 m depth range. The female hammerhead tracked in November 2008 undertook nightly movements offshore to an area $5.6 \mathrm{~km}$ east of Wolf, returning before dawn each day (Fig. 10). In a similar fashion to the previous shark, daytime movements centered at Shark Point and Rockfall, although these extended to cover the entire eastern coastline of Wolf and included some early morning from 0400 to $0600 \mathrm{~h}$ movements around the southern point of the island and Elephant Rock (letters G and E in Fig. 10).
Swimming depths while close to the island did not generally exceed $50 \mathrm{~m}$. Similar depths were maintained while making non-directional movements offshore (letters $\mathrm{A}$ and $\mathrm{C}$ in Fig. 10). However, the shark made several deep dives to depths 100-300 m when making directional movements out to the open ocean in the evening and on return trips before daybreak (letters B and D in Fig. 10). Neither individual ever ventured along the north or west of Wolf during the tracks.

Inter-island movements

Hammerhead sharks, tagged at Darwin Island (a distance of $38 \mathrm{~km}$ from Wolf), migrated across open water and
Fig. 9 Sphyrna lewini. Tracks for male hammerhead $(2.2 \mathrm{~m}$ TL), $11 / 2 / 200712: 18$ to 11/4/2007 8:01; at Wolf Island using onboard directional hydrophone. Kernels show intensity of spatial usage $(95 \%$ kernel: $0.29 \mathrm{~km}^{2}, 50 \%$ kernel: $0.05 \mathrm{~km}^{2}$ )

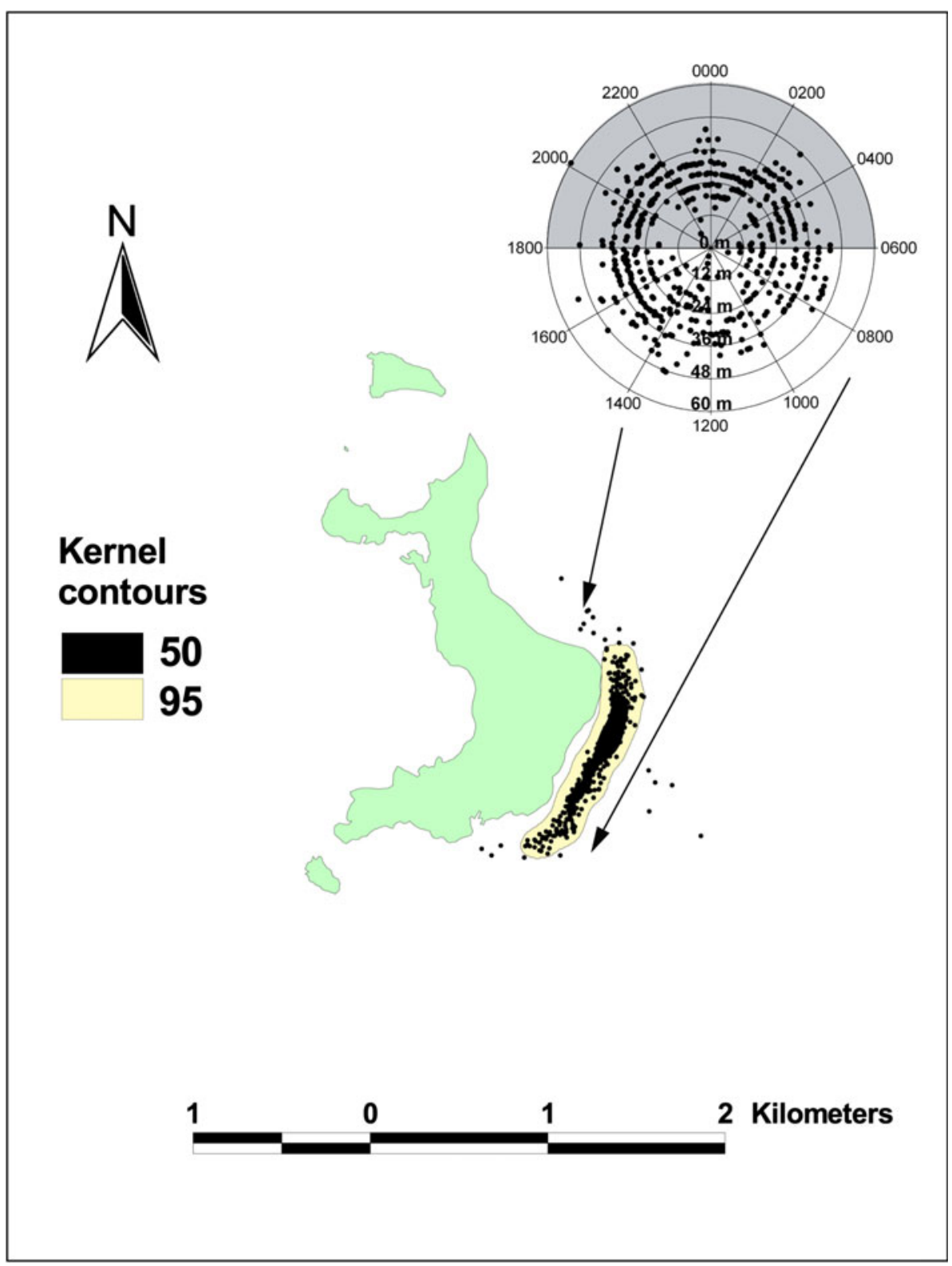


Fig. 10 Sphyrna lewini. Tracks for female hammerhead (2 m TL), 11/17/2008 11:51 to $11 / 19 / 200820: 16$ ) at Wolf Island using onboard directional hydrophone. Kernels show intensity of spatial usage. Kernel Areas for Track_Nov 08. 95\% kernel: $19.8 \mathrm{~km}^{2}, 50 \%$ kernel: $1.15 \mathrm{~km}^{2}$

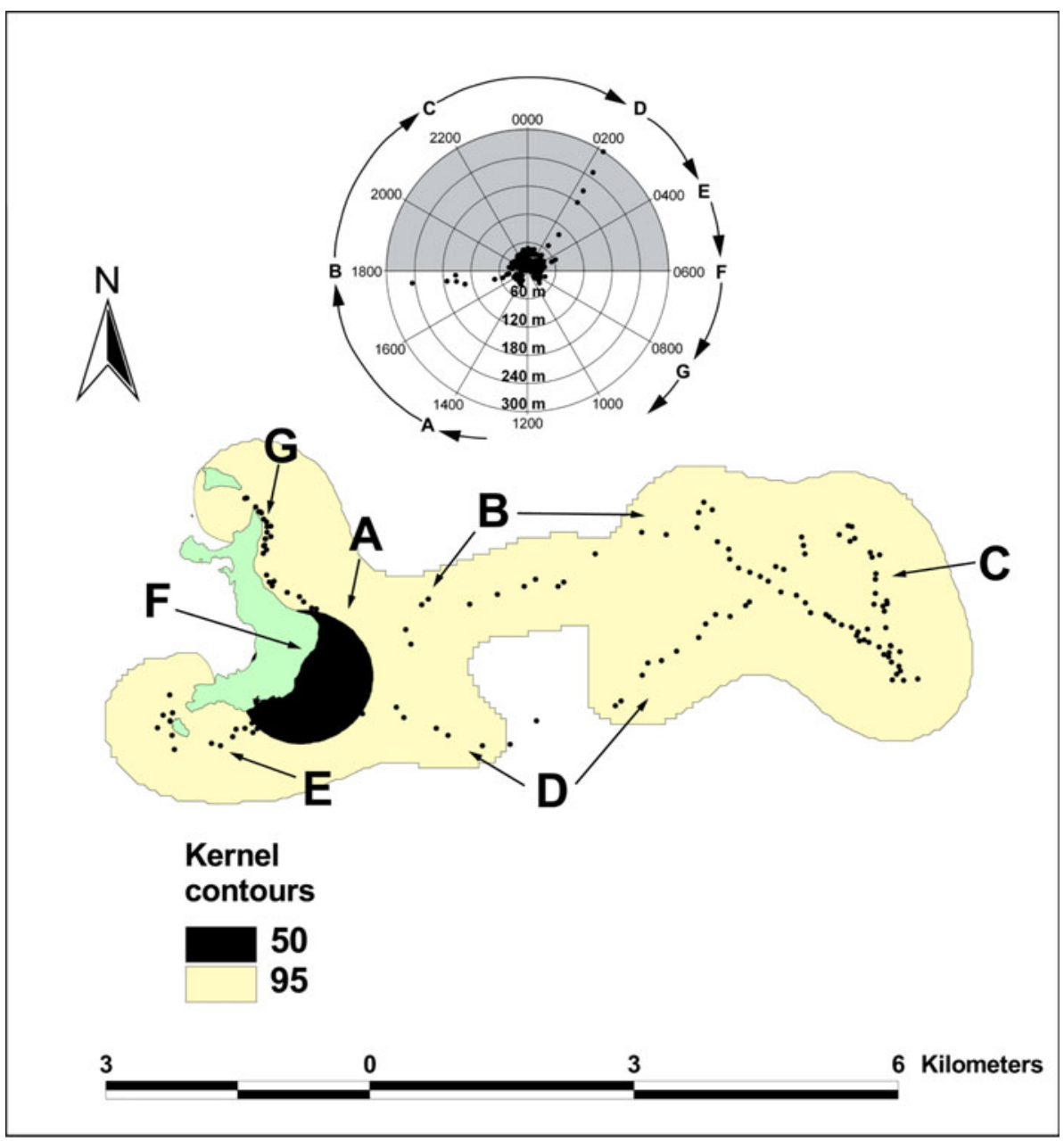

eventually took up residence at Shark Point, the "hotspot" at Wolf. A total of 17 trips from Darwin to Wolf were made by the hammerheads tagged at Darwin Arch. Of these, only two were first recorded at Shark Point, the "hot spot" on Wolf Island. On eight occasions, the shark was first recorded at Elephant Rock, although briefly-in most of these cases, the shark spent less than 3 min at Elephant Rock, and generally became resident at the Shark Point site, appearing to circle between Shark Point, Rockfall, and East Bay in daylight hours, for the next several days. In a similar fashion, the sharks tagged at Wolf also made frequent migrations to Darwin Arch and back. Shark \#38 for example was tagged at Wolf on October 29, remained resident at the hotspot for one month and then migrated to Darwin. It stayed at the Arch for a week then returned to Wolf. It was first detected at Elephant Rock on December 7 at 13:12 and was present at that site for $21 \mathrm{~min}$, before appearing at Rockfall at 14:46. It spent the next 3 weeks circling between Rockfall, Shark Point, and East Bay in daytime hours, with absences of several hours most nights. It returned to Darwin for one day in early January. The shark was not recorded at Elephant Rock again until January 22, when it was detected for 3 min after returning from Darwin and before moving, again, to the southeastern face of Wolf for several days.

Only one of the hammerheads tagged at Darwin that migrated to Wolf was not detected at Shark Point (Table 4). The first records in Wolf of seven of these sharks occurred between 12 and 24 November. The shortest time taken by a Darwin hammerhead to move between the two islands was 11:56 h, implying a mean swimming speed of $0.88 \mathrm{~ms}^{-1}$ over the straight-line distance of $38 \mathrm{~km}$. However, most migrations took between 1 and 10 days, suggesting that most of these migrations were not direct (Table 5).

There appeared also to be a hotspot, where the sharks congregated, at Darwin Island. Visual censuses such as those carried out for Wolf (Fig. 3) showed a similar temporal pattern (January: 232 sharks/diver/h; May: 0 sharks/ diver/h; July: 12.5 sharks/diver/h; November: 100 sharks/ diver/h). Of the ten sharks tagged at the island, Darwin Arch received significantly more detections than Darwin 
Table 4 Sphyrna lewini. Number of detections of hammerheads tagged at Darwin Arch at sites around Darwin and Wolf Islands

\begin{tabular}{|c|c|c|c|c|c|c|c|c|c|}
\hline \multirow[t]{2}{*}{ Shark ID } & \multirow[t]{2}{*}{ Last detection } & \multicolumn{2}{|c|}{ Darwin } & \multicolumn{5}{|l|}{ Wolf } & \multirow[t]{2}{*}{ Total } \\
\hline & & Arch & Stack & Rockfall & East Bay & Elephant & Shark Point & Anchorage & \\
\hline 62 & $1 / 3 / 2008$ & 1,646 & 11 & 12 & 5 & 2 & 3 & 2 & 1,681 \\
\hline 63 & $1 / 29 / 2008$ & 1,011 & 28 & 198 & 4 & 2 & 899 & 3 & 2,145 \\
\hline 64 & $11 / 23 / 2007$ & 119 & 25 & 12 & & 7 & 98 & & 261 \\
\hline 65 & $12 / 11 / 2007$ & 14 & & 2 & & & 2 & & 18 \\
\hline 66 & $1 / 25 / 2008$ & 662 & & 82 & & 7 & 2,226 & 2 & 2,979 \\
\hline 67 & $7 / 10 / 2008$ & 106 & 24 & 170 & & 38 & 380 & 25 & 743 \\
\hline 68 & $2 / 20 / 2008$ & 292 & 4 & & & 16 & & & 312 \\
\hline 69 & $12 / 27 / 2007$ & 254 & & 2 & & 5 & 98 & 5 & 364 \\
\hline 70 & $1 / 28 / 2008$ & 248 & 1 & 180 & & 6 & 454 & 1 & 890 \\
\hline 71 & $1 / 13 / 2008$ & 723 & 13 & & & & & & 736 \\
\hline Total & & 5,490 & 106 & 658 & 9 & 83 & 4,160 & 38 & 10,544 \\
\hline
\end{tabular}

All sharks tagged on 10/29/2007

Table 5 Sphyrna lewini. Movements between Darwin and Wolf Islands

\begin{tabular}{lll}
\hline & Wolf-Darwin & Darwin-Wolf \\
\hline Number of trips & 61 & 38 \\
Mean travel time (hh:mm:ss) & $293: 08: 37$ & $471: 53: 37$ \\
StDev (hh:mm) & 48.59 & 31.29 \\
Max travel time (hh:mm:ss) & $9,055: 49: 00$ & $3,455: 54: 00$ \\
Min travel time (hh:mm:ss) & $12: 09: 00$ & $11: 56: 00$ \\
Distance (km) & 38 & 38 \\
Max straight-line speed $\left(\mathrm{ms}^{-1}\right)$ & 0.87 & 0.88 \\
\hline
\end{tabular}

Stack, which was located on the western coast of the island and was the site displaying the highest number of detections overall. Darwin Stack received a total of 51 visits from the ten sharks over the study period; however, the median length of visits was only $1 \mathrm{~min}(\mu=3.5 \mathrm{~min})$, indicating that sharks were passing through this site, rather than residing. The Arch at Darwin Island and Shark Point at Wolf Island received longer and more frequent visits from these ten sharks than the other locations. These were the only two sites in which uninterrupted visits of over $1 \mathrm{~h}$ occurred. The mean number of visits by the ten Darwin hammerheads to Shark Point was 60, whereas the mean number of visits at the Arch was 105. This indicated a high degree of residency at these two sites. On the contrary, Elephant and Anchorage at Wolf and Darwin Stack all showed a similar pattern of fewer, short visits, probably of individuals simply passing through these sites on an infrequent basis. East Bay and Rockfall (to the northern and southern limits of Shark Point, respectively) displayed an intermediate residence time (Fig. 11).

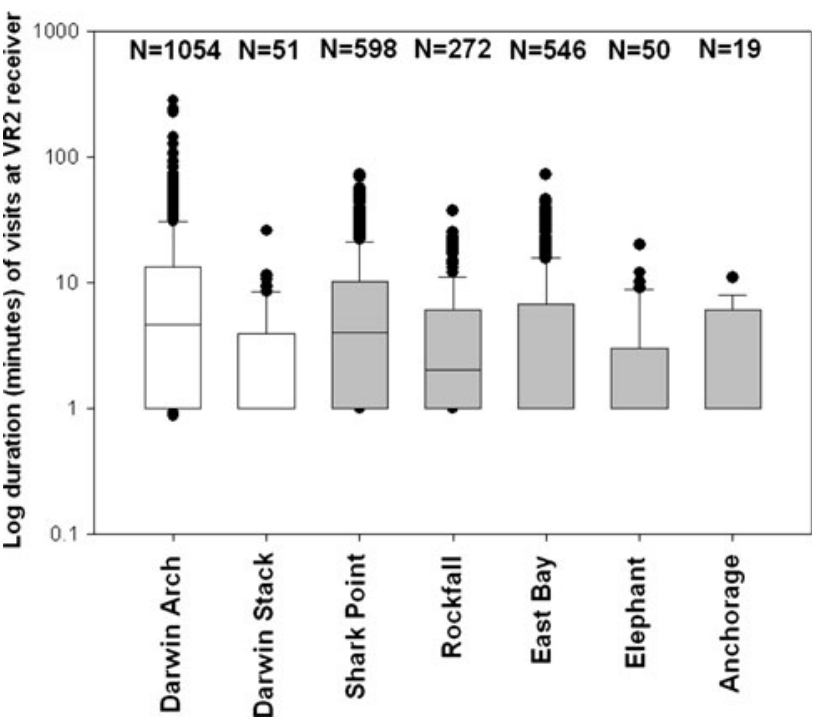

Fig. 11 Sphyrna lewini. Residence time (median and quartiles) in minutes for Darwin sharks at sites in Darwin(white) and Wolf (gray), $N=$ total number of visits

\section{Other species}

The pelagic assemblage appeared richer at the southeastern corner of Wolf, in accordance with the distribution of hammerheads. Representing lower-level trophic groups, steel pompano (Trachinotus stilbe) and several species of jacks (Caranx spp.), which feed on smaller fish and crustaceans, were observed, including the bluefin trevally (C. melampygus) and the most commonly found big-eye trevally (C. sexfasciatus), often found in mating pairs, with the darker-colored male shadowing the lighter female. The pelagic fishes were largely confined to the three sites on the southeastern coast of the island, East Bay, Shark Point, and 
Fig. 12 Relative average normalized abundance of pelagic species around Wolf Island in 2008. 1 Scalloped hammerhead shark, 2 Jacks, 3 Steel pompano, 4 Galapagos shark, 5 Bottlenose dolphin, 6 Snappers, and 7 Yellowfin tuna

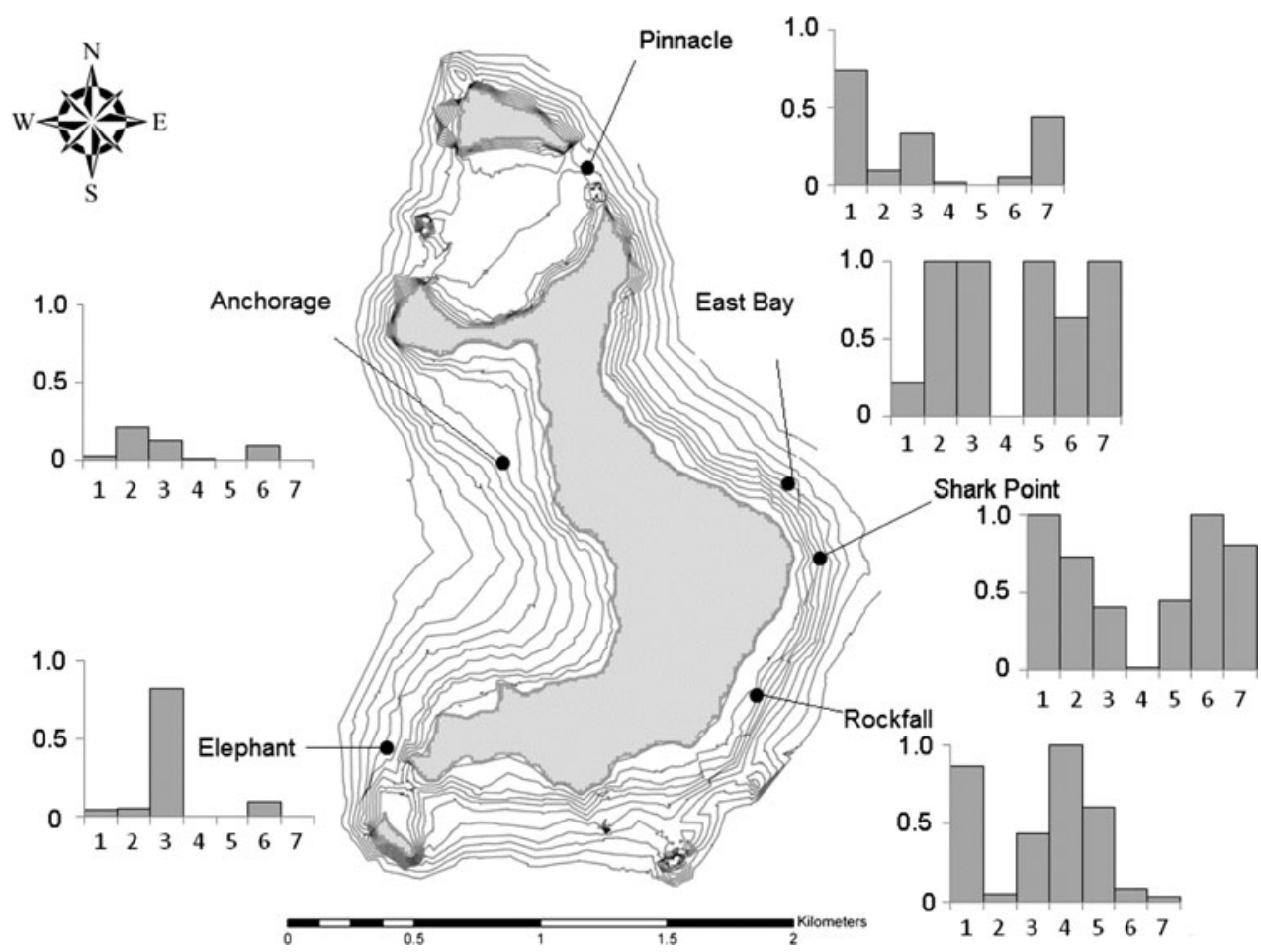

Rockfall and not the one site on the northeastern coast, the Pinnacle, or the two sites on the western coast, the Anchorage and Elephant Rock (Fig. 12). The normalized abundance of scalloped hammerhead sharks was 1.0 at Shark Point. The normalized scores of the jacks and steel pompano were 1.0 at the East Bay, while the score for the Galapagos sharks was 1.0 at the Rockfall. The highest abundances of dolphins were recorded at the East Bay; the snappers were most common at Shark Point. Yellow snapper (Lutjanus argentiventris) were observed in higher numbers at Shark Point and East Bay. If one were to average out the abundances across taxonomic groups, the abundance of pelagic fishes would be roughly evenly divided by the three sites on the eastern side of the island.

\section{Discussion}

Wolf Island is one of the remotest parts of the Galapagos archipelago_it is $38 \mathrm{~km}$ distant from Darwin, an even smaller island to the north, and over $140 \mathrm{~km}$ distant from the northern coasts of Pinta and Isabela Islands to the south. The seabed in the surrounding ocean reaches $1,000 \mathrm{~m}$ (Harpp and Geist 2002). Like at many other mid-ocean structures (for review, see Uchida and Tagami 1986), we found a high abundance of top predators, especially hammerhead sharks, and other pelagic organisms around the island. Our results from several independent methods showed that these were not distributed homogeneously around the island but displayed a preference for the southeastern corner. In the absence of fisheries-dependent data, telemetric and visual techniques are shown to complement one another. Determining absolute abundance using underwater censuses is problematic due to limited visibility, and comparative abundance indices may also reflect changing conditions between sites. However, when combined with detection data from receivers at each census site and movement patterns from tracking a limited number of individuals, it is possible to build a convincing case for seasonal site residence and fidelity. In the case of hammerhead sharks, individuals were clearly resident along the southeastern corner of Wolf for extended periods. The loss of the receiver at Pinnacle may have biased these results, but for the period when the receiver was operational (until December 2007), only 19 sharks for an average of 48 detections per individual were recorded at the site (a total of 928 detections), in comparison with over 15,000 detections for Shark Point and Rockfall for the same period, so this indicates that the site may be of lesser importance, at least for that period.

Hammerheads tagged at Darwin showed a similar preference for the southeastern corner of Darwin. Most tagged sharks migrated at least once between the two "hotspots", while many made several of these migrations. Other sites around both islands detected sharks passing through infrequently, yet it was unusual for individuals to remain at these sites for more than a few minutes. In addition, the hotspots were favored by other pelagic species, such as pompano, jacks, tuna, and bottlenose dolphin. Why would all these species limit their use of the island's 
coastal waters to these specific sites? In the case of hammerhead sharks, what triggers a movement between hotspots on different islands?

SeaWifs satellite images of surface chlorophyll-a concentration show a patch of higher chlorophyll trailing to the northwest of Wolf and also of Darwin (Palacios 2002). This is consistent with the existence of a strong, persistent, unidirectional flow from the southeast to the northwest. Water coming into contact with the islands is diverted toward the surface and provides conditions for enhanced primary production, yet this is expressed not at the island itself, but in the eddies formed downstream by the current (Barton 2001). Enhanced primary production downstream of oceanic islands and seamounts can form the basis of an enhanced pelagic assemblage (Genin 2004), and yet in the case of Darwin and Wolf, the greatest abundance and diversity of pelagic organisms are mostly restricted to the upstream faces of the coast. Doty and Oguri (1956) noted upstream effects where the current stalls as it splits to flow around the obstacle. This may cause an area of entrainment, which might provide the basis for a subsidized food source upstream of the island. Another possibility is that enhancement of fluxes of near-bottom food particles caused by the interactions between abrupt, sloping topography of seamounts and the impact of currents, tides, and internal waves may support high densities of resident fish above seamounts (Mohn and Beckmann 2002). Increased flow of particles augments growth and recruitment of benthic suspension feeders, which results in rich benthic communities at exposed sites of seamounts (Genin et al. 1986). These rich benthic communities, in turn, constitute an important source of food for benthivorous fish (Genin 2004). Hamner et al. $(1988,2007)$ suggest that planktivorous fishes on the upstream reef face form a "wall of mouths" that remove most of the zooplankton from the water near the reef face before that water physically impinges upon the reef surface. In the case of the hotspot at the southeast of Wolf, planktivorous pelagic and reef fish may be behaving in the same manner, and thus in turn, providing an augmented food source for the piscivorous fish and top predators observed in this study, many of which were seen feeding at the island.

Schools of hammerhead sharks were mainly made up of females, as reflected by the sex ratio of tagged individuals (only six males were tagged during the study). Aggregations of females at seamounts were noted by Klimley (1987), who suggested that females migrate from continental waters to offshore islands and seamounts at an earlier age than males. Dietary analysis showed that small males fed more on benthic prey, whereas small females and large hammerheads fed mainly on neritic and pelagic prey. He postulated that females migrated earlier in order to have access to better food supplies and therefore attained the larger sizes required for reproduction earlier than males. The schooling behavior of hammerheads is thought to respond to the central refuging theory (Hamilton and Watt 1970)—predators minimize activity when not foraging by remaining at a single central location within their home range. Additional benefits to this include the ease of social interactions and mating (Klimley and Nelson 1984). By schooling at sites of high abundance and diversity of other fish, they might also maximize their exposure to the services of cleaning fish, which remove parasites from their skin surface (Gooding and Magnuson 1967). Cleaning behavior was observed frequently at both Shark Point and Darwin Arch, and both sites are attractive to dive tourists for this reason.

It is possible that hammerhead schools may remain along the coast of Wolf to take advantage of reduced currents, so that they do not have to swim so fast when in their resting phase of the diel cycle; however, Klimley and Nelson (1984) studied the distribution of hammerheads around a seamount with changing current patterns and found that they did not change their position to compensate for these changes, which suggests that rheotaxis is unlikely. They suggest that certain sites may serve as "landmarks" used in daily movement behavior-in addition to the current study, site fidelity to particular regions of oceanic structures has been observed at Espiritu Santo seamount in the Gulf of California, Mexico (Klimley et al. 1988) and at Malpelo Island, Colombia (Bessudo et al. unpublished data). In all three cases, the hammerheads displayed a pronounced diel pattern to their presence at the island throughout the year and regardless of the site-individuals tended to spend daytime hours at the island, leaving around dusk and returning in the early hours or around dawn. This behavior was also found by continually tracking the female hammerhead shark (Fig. 10), although not in the case of the male hammerhead (Fig. 9). Diel homing behavior has been described for pelagic species associated with midocean structures, including hammerheads (Klimley and Nelson 1984) and yellowfin tuna (Klimley and Holloway 1999). Hammerheads tend to feed at night on epipelagic prey (Klimley 1987; Torres-Rojas et al. 2006). Throughout this study, none were ever seen feeding at the island, in contrast to observations of both dolphins and Galapagos sharks. Hammerheads undertook both homing and highly directional swimming behavior (Klimley 1993; this study and Ketchum et al. in prep.). It is unlikely that these characteristics of their diel movement patterns are related to sea surface irradiance or seabed topography; however, they would appear to require the ability to detect and interpret some environmental property, both in order to undertake their daily movements and to discriminate between hotspot sites and adjacent non-hotspot sites. Klimley (1993) noticed that the nightly foraging paths of 
hammerheads often followed areas of maximum or minimum geomagnetic gradient. He proposed that the electrical current induced by the shark swimming through lines of differing magnetic force resulted in a voltage differential between the Ampullae of Lorenzini on either side of the shark's head (thus the "hammer" shape) and that this differential could be used to navigate.

Alternatively, the southeastern corner of Wolf may be the most suitable site from which to stage nightly foraging trips into open waters to feed on epipelagic prey. The hammerhead tracked in this study that made nightly trips always did so to the east and southeast of the islandalthough this must be treated as anecdotal evidence as this refers to one individual on three successive nights. The shark may be following geomagnetic pathways to feeding grounds-the area of influence of shallow seamounts and islets can be up to $20-30 \mathrm{~km}$ (Morato et al. 2008), so feeding may be a reason for the hammerhead aggregations-it simply takes place further offshore and not at the island itself. It may also be that sharks at the hotspot can detect areas of high prey density upstream and therefore access them more quickly at nightfall. This would imply, however, that they are able to detect their prey from a distance of several kilometers, perhaps chemically.

The design of zonation schemes for multi-use marine reserves is often a highly controversial and politicized process (Baine et al. 2007; Heylings et al. 2002) and in many cases, such as in the MPAs of the Eastern Tropical Pacific, there is a lack of information regarding the spatial distribution of the local biodiversity. This makes it difficult to provide technical advice on the design and spacing of No-Take Areas based either on the spatial ecology of key species or on an evaluation of the marine community makeup. In the case of the Galapagos, this was recognized in the Marine Reserve Management Plan, so that the original zonation scheme implemented in 2002 was given a provisional designation (Heylings et al. 2002). By using the scalloped hammerhead shark as condition indicator species, more appropriate protection might be provided to the marine community by closing the areas where this species aggregates, and extending this protection outward to include the area covered during nocturnal foraging movements as part of a new zonation scheme for the GMR (Ketchum et al. 2009), as the hammerhead's range may also meet the needs of other species at lower trophic levels (see Sergio et al. 2008).

Acknowledgments The authors would like to thank the Galapagos National Park Service, the Charles Darwin Foundation and UC Davis for the institutional support of the Galapagos Shark Research Program. Thanks also to Conservation International, WWF-Galapagos, Galapagos Conservancy, Oak Foundation, Lindblad Expeditions, and Galapagos Conservation Trust for funding and support. The crew of the MV Sierra Negra, MN Queen Mabel, and FM Arrecife provided invaluable logistics and support. We are indebted to Scott Henderson, Maria Elena Guerra, Pablo Guerrero, Priscilla Martinez, Eliecer Cruz, Patricia Zárate, German Soler, Roby Pépolas and Julio Delgado, to Tito Franco and his assistants and to all the Galapagos guides, National Park Wardens, and other Charles Darwin Foundation biologists who participated in fieldwork activities. Special thanks are also due to INGALA for emergency transport of tags and to TAME Airlines.

Open Access This article is distributed under the terms of the Creative Commons Attribution Noncommercial License which permits any noncommercial use, distribution, and reproduction in any medium, provided the original author(s) and source are credited.

\section{References}

Alpine JE, Hobday AJ (2007) Area requirements and pelagic protected areas: is size an impediment to implementation? Mar Fresh Res 58:558-569

Arauz R, Antoniou A (2006) Preliminary results: movements of scalloped hammerhead sharks (Sphyrna lewini) tagged in Cocos Island National Park, Costa Rica, 2005. Memoria: Primer Seminario Taller Sobre el Estado del Conocimiento de la Condrictio fauna de Costa Rica. pp 8-9 (in Spanish)

Baine M, Howard M, Kerr S, Edgar G, Toral V (2007) Galapagos Islands and the Archipelago of San Andres: issues, problems and opportunities. Ocean Coast Manag 50:148-173

Banks S (2002) Ambiente Físico. In: Danulat E, Edgar GJ (eds) Reserva Marina de Galápagos. Linea Base de la Biodiversidad. Fundación Charles Darwin y Servicio Parque Nacional de Galápagos, Santa Cruz, pp 22-35 (in Spanish)

Barton ED (2001) Island wakes. In: Steele JH, Thorpe SA, Turekian KK (eds) Encyclopedia of ocean sciences, vol 3 I-M. Academic Press, San Diego, pp 1397-1403

Batschelet E (1981) Circular statistics in biology. Academic Press, London

Baum JK, Myers RA (2004) Shifting baselines and the decline of pelagic sharks in the Gulf of Mexico. Ecol Lett 7:135-145

Baum J, Myers R, Kehler DG, Worm B, Harley SJ, Doherty PA (2003) Collapse and conservation of shark populations in the Northwest Atlantic. Science 299:389-392

Black J (1973) Galapagos Archipielago del Ecuador. Fundacion Charles Darwin para las islas Galapagos, Quito

Boelhert GW, Genin A (1987) A review of the effects of seamounts on biological processes. In: Keating BH, Fryer P, Batiza R, Boelhert GW (eds) Seamounts, islets and atolls. Geophysical Monograph 43, American Geophysical Union, Washington, DC, pp 319-334

Calvopiña M, Visaira R, Cruz E, Piu M, Dumas J (2006) Implementacion de la zonificacion consensuada de la reserva marina de Galapagos. In: Paz C, Monsalve G, Calvopina M (eds) Pasos hacia la sustentabilidad de la Reserva Marina de Galapagos. USAID-WWF Technical Report, Galapagos, pp 105-111

Crowder LB, Myers RA (2001) A comprehensive study of the ecological impacts of the worldwide pelagic longline industry. first annual report to the pew charitable trusts

Doty MS, Oguri M (1956) The island mass effect. J Cons Int Explor Mer 22:33-37

Edgar GJ, Banks S, Fariña JM, Calvopiña M, Martínez C (2004) Regional biogeography of shallow reef fish and macro-invertebrate communities in the Galapagos archipelago. J Biogeog $31: 1-18$ 
Genin A (2004) Bio-physical coupling in the formation of zooplankton and fish aggregations over abrupt topographies. J Mar Syst 50:3-20

Genin A, Dayton PK, Lonsdale PF, Spiess FN (1986) Corals on seamount peaks provide evidence of current acceleration over deep-sea topography. Nature 322:59-61

Gooding RM, Magnuson JJ (1967) Ecological significance of a drifting object to pelagic fishes. Pac Sci 21:486-497

Grove JS, Lavenberg RJ (1997) The fishes of the Galápagos islands. Stanford University Press, Stanford

Hamilton WJ, Watt KE (1970) Refuging. In: Johnston RF, Frank PW, Michener CD (eds). Annu Rev Ecol Syst 1:263-287

Hamner WM, Hauri IR (1981) Effects of island mass: water flow and plankton pattern around a reef in the Great Barrier Reef lagoon, Australia. Limnol Oceanogr 26(6):1084-1102

Hamner WM, Jones MS, Carlton JH, Hauri IR, Williams DM (1988) Zooplankton, planktivorous fish and wáter currents on a windward reef face: Great Barrier Reef, Australia. Bull Mar Sci 42(3):459-479

Hamner WM, Colin PL, Hamner PP (2007) Export-import dynamics of zooplankton on a coral reef in Palau. Mar Ecol Prog Ser 334:83-92

Harpp K and Geist D (2002) Wolf-Darwin Lineament and plumeridge interaction in northern Galapagos. Geochem Geophys Geosyst 3(11):8504

Hearn A, Ketchum J, Shillinger G, Klimley AP, Espinoza E (2008) Programa de Investigación y Conservación de Tiburones en la Reserva Marina de Galápagos. Reporte Anual 2006-7. Fundación Charles Darwin, Santa Cruz, p 114 (in Spanish)

Heithaus M, Frid A, Wirsing AJ, Worm B (2008) Predicting ecological consequences of marine top predator declines. Trends Ecol 23(4):202-210

Heublein J, Kelly JT, Crocker CE, Klimley AP, Linley ST (2009) Migration of green sturgeon, Acipenser medirostris, in the Sacramento River. Env Biol Fishes 84(3):245-258

Heylings P, Bensted-Smith R, Altamirano M (2002) Zonificación e historia de la Reserva Marina de Galápagos. In: Danulat E, Edgar GJ (eds) Reserva Marina de Galápagos. Linea Base de la Biodiversidad. Fundación Charles Darwin y Servicio Parque Nacional de Galápagos, Santa Cruz, pp 10-22 (in Spanish)

Holland K, Brill RW, Chang RKC (1990) Horizontal and vertical movements of yellowfin and bigeye tuna associated with fish aggregating devices. Fish Bull US 88:493-507

Holland KN, Lowe CG, Peterson JD, Gill A (1992) Tracking coastal sharks with small boats: hammerhead shark pups as a case study. Aust J Mar Freshwat Res 43(1):61-66

Houvenaghel GT (1984) Oceanographic setting of the Galapagos Islands. In: Perry R (ed) Key environments: Galapagos. Pergamon Press, Oxford, pp 43-54

Human P, DeLoach N (2003) Reef fish identification: Galápagos. New World Publications, Quito

Kelly JT, Klimley AP, Crocker CE (2007) Movements of green sturgeon Acipenser medirostris, in the San Francisco Bay estuary, California. Env Biol Fishes 79:281-295

Ketchum J, Hearn A, Shillinger G, Espinoza E, Peñaherrera C, Klimley P (2009) Shark movements and the design of protected pelagic environments within and beyond the Galapagos Marine Reserve. Proceedings of the Galapagos Science Symposium, Puerto Ayora

Ketchum J, Hearn A, Klimley AP, Espinoza E (in prep) Diel and seasonal movements of hammerhead sharks in the Galapagos Islands, Ecuador

Klimley AP (1987) The determinants of sexual segregation in hammerhead sharks Sphyrna lewini. Env Biol Fish 18(1):27-40

Klimley AP (1993) Highly directional swimming by scalloped hammerhead sharks, Sphyrna lewini, and subsurface irradiance, temperature, bathymetry, and geomagnetic field. Mar Biol 117: $1-22$

Klimley AP, Holloway CF (1999) School fidelity and homing synchronicity of yellowfin tuna, Thunnus albacares. Mar Biol 133:307-317

Klimley AP, Nelson DR (1984) Diel movement patterns of the scalloped hammerhead shark (Sphyrna lewini) in relation to El Bajo Espiritu Santo: a refuging central-position social system. Behav Ecol Sociobiol 15:45-54

Klimley AP, Butler SB, Nelson DR, Stull AT (1988) Diel movements of scalloped hammerhead sharks, Sphyrna lewini Griffith and Smith to and from a seamount in the Gulf of California. J Fish Biol 33:751-761

Klimley AP, Beavers SC, Curtis TH, Jorgensen SJ (2002) Movements and swimming behavior of three species of sharks in La Jolla Canyon, California. Env Biol Fishes 63:117-135

Klimley AP, Kihslinger RL, Kelly JT (2005) Directional and nondirectional movement of bat rays Myliobatis californica, in Tomales Bay, California. Env Biol Fishes 74:79-88

Lorance P, Uiblein F, Latrouite D (2002) Habitat, behavior and colour patterns of orange roughy Hoplostethus atlanticus (Piscis: Trachichthyidae) in the Bay of Biscay. J Mar Biol Assoc UK 892:321-331

McFarland W, Levin SA (2002) Modelling the effects of current on prey acquisition in planktivorous fishes. Mar Freshw Behav Physiol 35:69-85

Mohn C, Beckmann A (2002) The upper ocean circulation at great Meteor Seamount. Part I: structure of density and flow fields. Ocean Dyn 52:179-193

Morato T, Varkey DA, Damaso C, Machete M, Santos M, Prieto R, Santos RS, Pitcher TJ (2008) Evidence of a seamount effect on aggregating visitors. Mar Ecol Prog Ser 357:23-32

Myers RA, Baum JK, Shepherd TD, Powers SP, Peterson CH (2007) Cascading effects of the loss of apex predatory sharks from a coastal ocean. Science 315:1846-1850

Ovetz R (2007) The bottom line: an investigation of the economic, cultural and social costs of high seas industrial longline fishing in the Pacific and the benefits of conservation. Mar Pol 31:217-228

Palacios DM (2002) Factors influencing the island-mass effect of the Galápagos. Geophys Res Lett 29(23):2134

Pauly D, Watson R (2003) Counting the last fish. Sci Am 289(1):42-47

Pauly D, Christiensen V, Dalsgaard J, Froese R, Torres F Jr (1998) Fishing down marine food webs. Science 279:860-863

Reyes H, Murillo J (2007) Esuferzos para el control de la pesca ilictia. Reporte Galapagos 2002-6, Fundacion Charles Darwin/INGALA/ Parque Nacional Galapagos, Galapagos

Roberts C (2003) Our shifting perspectives on the oceans. Oryx 37(2):166-177

Seaman DE, Powell RA (1996) An evaluation of the accuracy of kernel density estimators for home range analyses. Ecology 77(7):2075-2085

Sergio F, Caro T, Brown D, Clucas B, Hunter J, Ketchum J, McHugh K, Hiraldo F (2008) Top predators as conservation tools: ecological rationale, assumptions, and efficacy. Annu Rev Ecol Evol Syst 39:1-19

Snell HM, Stone PA, Snell HL (1996) Special paper: a summary of geographical characteristics of the Galapagos Islands. J Biogeog 23(5):619-624

Stevens JD, Bonfil R, Dulvy NK, Walker PA (2000) The effects of fishing on sharks, rays and chimaeras (Chondrychthyans), and the implications for marine ecosystems. ICES J Mar Sci 57:476-494

Stevenson C, Katz LS, Micheli F, Block B, Heiman KW, Perle C, Weng K, Dunbar R, Witting J (2007) High apex predator biomass on remote Pacific islands. Coral Reefs 26:47-51

Torres-Rojas Y, Hernandez-Heredia A, Galván-Magaña F (2006) Feeding habits of the scalloped hammerhead shark, Sphyrna 
lewini, in Mazatlán waters, southern Gulf of California, Mexico. Cybium 30(4):85-90

Uchida RN, Tagami M (1986) Groundfish fisheries and research in the vicinity of seamounts in the north Pacific Ocean. Mar Fish Rev 46:1-17

Welch DW, Rechisky EL, Melnychuk MC, Porter AD, Walters CJ, Clements S, Clemens BJ, McKinley RS, Schrek C (2008) Survival of migrating salmon smolts in large rivers with and without dams. PLOS Biology 6(10):2101-2108

Worm B, Lotze HK, Myers RA (2003) Predator diversity hotspots in the Blue Ocean. Proc Nat Acad Sci USA 100(17):9884-9888
Worm B, Barbier EB, Beaumont N, Duffy JE, Folke C, Halpern BS, Jackson JBC, Lotze HK, Micheli F, Palumbi SR, Stachowitz JJ, Watson R (2006) Impacts of biodiversity loss on ocean ecosystem services. Science 314:787-790

Worton BJ (1989) Kernel methods for estimating the utilization distribution in home-range studies. Ecology 70:164-168

Yuen HSH (1970) Behavior of skipjack tuna, Katsuwonis pelamis, as determined by tracking with ultrasonic devices. J Fish Res Bd Can 27:2071-2079 